\title{
SUVREMENI PRAVNI IZAZOVI SMANJENJA EMISIJA STAKLENIČKIH PLINOVA IZ POMORSKOG PROMETA - MEĐUNARODNA I EUROPSKA PERSPEKTIVA
}

\author{
UDK: 504.7:656.61 (100) \\ DOI: $10.31141 /$ zrpfs.2020.57.137.739 \\ Izvorni znanstveni rad \\ Primljeno: 10. II. 2020.
}

\begin{abstract}
Iznoseći pregled pravnih akata čija rješenja, kao rezultat aktivnih klimatsko-pomorskih politika na europskoj i globalnoj razini, jamče smanjenje emisija stakleničkih plinova u pomorskom prometu - autorica ukazuje na značaj rješenja o uvođenju obveznih, globalnih, minimalnih standarda energetske učinkovitosti brodova u međunarodnoj plovidbi. Osnovno polazište ovog istraživanja čini analiza Pravila 22A izmijenjenog Priloga VI. Konvencije MARPOL kojim se uspostavlja pravni okvir obveznog globalnog sustava prikupljanja podataka o potrošnji loživih ulja na brodovima (IMO DCS), a prema kojemu su, od 1. siječnja 2019. godine, brodari dužni prikupljati podatke o potrošnji goriva za brodove iznad $5000 \mathrm{BT}$ u međunarodnoj pomorskoj plovidbi te izvještavati o potrošnji goriva od ožujka 2020. godine. U radu se posebna pozornost posvećuje analizi regulatorne aktivnosti europskog zakonodavstva iz 2019. godine u odnosu na Prijedlog Uredbe Europskog parlamenta i Vijeća o izmjeni Uredbe (EU) 2015/757 i nastojanja ostvarivanja potpune usklađenosti europskog i globalnog sustava prikupljanja podataka o emisijama i potrošnji goriva na brodovima, a u cilju smanjenja emisija stakleničkih plinova iz pomorskog prometa. U središtu pozornosti su pitanja ocjene uspješnosti usklađivanja rješenja Uredbe (EU) 2015/757 s globalnim sustavom IMO DCS prema Prijedlogu Uredbe Europskog parlamenta i Vijeća o izmjeni Uredbe (EU) 2015/757 iz 2019. godine.
\end{abstract}

Ključne riječi: smanjenje emisija stakleničkih plinova, pomorski promet, pravni izazovi

\section{UVOD}

Ukupnoj emisiji stakleničkih plinova pridonosi promet sa 14 posto $^{1}$ od kojih brodovi doprinose sa 3 posto. ${ }^{2}$ Rast svjetske trgovine i odvijanje suvremenog pomorskog prometa možemo pratiti kao proporcionalne veličine s obzirom na to da povećanje svjetske trgovine znači i povećanje pomorskog prometa. Pomorski je

1 Detaljnije o prometu kao uzroku nastajanja emisija stakleničkih plinova u razdoblju 1990. - 2015. god. vidjeti u Sources of Greenhouse Gas Emissions, dostupno na: https:/www.epa.gov/ghgemissions/ sources-greenhouse-gas-emissions.

2 RAHIM, M. M.; ISLAM, T.; KURUPPU, S.: „Regulating global shipping corporations’ accountability for reducing greenhouse gas emissions in the seas“, Marine Policy, vol. 69, 2016., str. 159. 
Izv. prof. dr. sc. Željka Primorac: Suvremeni pravni izazovi smanjenja emisija stakleničkih plinova iz... Zbornik radova Pravnog fakulteta u Splitu, god. 57, 3/2020, str. 739-757

promet pokretač ${ }^{3}$ globalne trgovinske razmjene i doprinositelj gospodarskog rasta, ali i rastućeg izvora emisija stakleničkih plinova ${ }^{4}\left(\mathrm{CO}_{2}\right.$ kao najznačajniji staklenički plin koji emitiraju brodovi, ${ }^{5}$ ali i drugih stakleničkih plinova poput $\mathrm{SO}_{x}, \mathrm{NO}_{\mathrm{x}}, \mathrm{CH}_{4}$ i dr.). Predviđa se kako bi rast svjetske pomorske trgovine mogao doprinijeti rastu emisija stakleničkih plinova između 50 i 250 posto do 2050 . godine ${ }^{6}$ pa možemo uvidjeti kako odvijanje međunarodnog pomorskog prometa ima značajan učinak na globalno obilježje emisija stakleničkih plinova negativno utječući na okoliš i klimatske promjene. Kada se govori o onečišćenju zraka s broda, prvenstveno se misli na emisije štetnih plinova s brodova kojima je glavni pogonski sustav dizelski motor, ${ }^{7}$ a brojne studije i nezavisna istraživanja plovidbenih pravaca pokazuju da se 70 posto i više emisija s brodova u međunarodnoj plovidbi javlja unutar $400 \mathrm{~km}$ od kopna. ${ }^{8}$ Budući da izgaranje fosilnih goriva (brodskog goriva) u pomorskom prometu rezultira povećanjem koncentracije stakleničkih plinova, ${ }^{9}$ autorica u radu iznosi i analizira europske i međunarodne mjere koje jamče smanjenje emisija stakleničkih plinova iz međunarodnog pomorskog prometa pridonoseći ostvarivanju okolišnih ciljeva europskih i globalnih klimatsko-pomorskih politika.

3 U zadnjih 100 godina flota se proširila sa 72.000 na 88.000 brodova te odgovarajućim povećanjem tonaže od 22,4 na 553 BT (EYRING, V.; ISAKSEN, I. S. A.; BERNTSEN, T., COLLINS, W. J.; CORBETT, J. J.; ENDRESEN, O.; GRAINGER, R. G.; MOLDANOVA, J.; SCHLAGER, H.; STEVENSON, D. S.: Transport impacts on atmosphere and climate: Shipping, Atmospheric Environment, 2009., str. 9).

4 Više vidi VIANA, M.; HAMMINGH, P.; COLETTE, A.; QUEROL, X.; DEGRAEUWE, B.; DE VLIEGER, I.; VAN AARDENNE, J.: Impact of maritime transport emissions on coastal air quality in Europe, Atmospheric Environment, vol. 90, 2014., str. 96.

5 POPEK, M.: Response of international shipping to the current environmental challenges, E3S Web of Conferences - SEED 2016., vol. 10, 2016., str. 2 (vidi COLLS, J.; TIWARY, A.: Air pollution, Measurement, Modelling and Mitigation, CRC Press, 2009., str. 130). Detaljnije o skupinama stakleničkih plinova vidi BROZOVIĆ, I.; REGENT, A.; GRGUREVIĆ, M.: „Emisije stakleničkih plinova, osobito iz prometa (Prilog analizi emisiji stakleničkih plinova, osobito iz prometa)“, Zbornik Veleučilišta u Rijeci, vol. 2, br. 1, 2014., str. 277. Više o utjecaju djelomične dekarbonizacije na pomorstvo vidi SHARMINA, M.; MCGLADE, C.; GILBERT, P., LARKIN, A.: „Global energy scenarios and their implications for future shipped trade“, Marine Policy, vol. 84, 2017., str. 21; WAN, Z.; EL MAKHLOUFI, A.; CHEN, Y., TANG, J.: „Decarbonizing the international shipping industry: Solutions and policy recommendations“, Marine Pollution Bulletin, br. 126, 2018., str. 429.

6 IMO, Greenhouse Gas Emissions, str. 1, dostupno na: http://www.imo.org/en/OurWork/ Environment/PollutionPrevention/AirPollution/Pages/GHG-Emissions.aspx). Više o različitim scenarijima budućeg rasta emisija iz pomorskog prometa vidi ZANNE, M.; TWRDY, E.: „Air pollution from maritime transport - the problem of today, the challenges of tommorow", Pomorstvo, vol. 25, br. 1, 2011., str. 106.

MILOŠEVIĆ-PUJO, B.; JURJEVIĆ, N.: „Onečišćenje mora iz zraka emisijom ispušnih plinova“, Naše more, br. 5-6, 2004., str. 181 .

8 EYRING, V.; CORBETT, J. J.; LEE, D. S.; WINEBRAKE, J. J.: Brief summary of the impact of ship emissions on atmospheric composition, climate, and human health, document submitted to the Health and Environment sub-group of the International Maritime Organization, 6. November 2007, dostupno na http://citeseerx.ist.psu.edu/viewdoc/download;jsessionid=C39FFDA797B8EBBD65F409C3E56B9FA4? doi=10.1.1.617.7361\&rep=rep1\&type=pdf, str. 2 .

9 Detaljnije vidi DULEBENETS, M. A.: „Green Vessel Scheduling in Liner Shipping: Modeling Carbon Emission Costs in Sea and at Ports of Call", International Journal of Transportation Science and Technology, vol. 7, br. 1, 2018., str. 26-27; GRITSENKO, D.: „Regulating GHG Emissions from shipping: Local, global, or polycentric approach?“, Marine Policy, vol. 84, 2017., str. 130-133. Više o potencijalu pomorskog sektora za smanjenje potrošnje goriva čak do 55 \% vidi Climate Action, European Commission, Time for international action on CO2 emissions from shipping, https://ec.europa.eu/clima/.../ shipping/.../marine_transport_en.pdf, str. 2. 


\section{EMISIJE STAKLENIČKIH PLINOVA IZ POMORSKOG PROMETA - GLOBALNA KLIMATSKO-POMORSKA POLITIKA}

Pitanja klimatskih promjena na globalnoj razini uređuje Protokol iz Kyota o klimatskim promjenama iz 1997. godine (Protokol iz Kyota) ${ }^{10}$ kao međunarodni sporazum vezan uz Okvirnu konvenciju Ujedinjenih naroda o klimatskim promjenama $^{11} \mathrm{i}$ jedan od najznačajnijih sporazuma o zaštiti okoliša. ${ }^{12}$ Donesen je u cilju usporavanja klimatskih promjena i smanjenja emisija ${ }^{13}$ stakleničkih plinova, ${ }^{14}$ ali se ne primjenjuje na stakleničke plinove nastale kao rezultat međunarodne plovidbe. ${ }^{15}$ U odnosu na smanjenje emisija stakleničkih plinova nastalih iz pomorskog prometa od iznimnog značaja jest Međunarodna konvencija o sprečavanju onečišćenja mora s brodova iz 1973. godine, ${ }^{16}$ temeljni preventivni međunarodnopravni akt o zaštiti morskog okoliša. ${ }^{17}$ Konvencija MARPOL unutar šest priloga normira tehničke i

10 Protokol iz Kyota prihvaćen je 11. prosinca 1997. god. na trećoj konferenciji stranaka Okvirne konvencije Ujedinjenih naroda o promjeni klime u Kyotu, a stupio je na snagu 16. veljače 2005 . god. Države su se njime obvezale da će u razdoblju 2008. - 2012. smanjiti emisije stakleničkih plinova za $5 \%$ u odnosu na razine iz 1990. god. (više vidi Green Paper on greenhouse gas emissions trading within the European Union, COM/2000/0087final, dostupno na: https://eur-lex.europa.eu/legal-content/EN/TXT/ PDF/?uri=CELEX:52000DC0087\&from=EN). Protokolom iz Kyota danas su vezane 184 države među kojima i RH (vidi Zakon o potvrđivanju Kyotskog protokola uz Okvirnu konvenciju Ujedinjenih naroda o promjeni klime, NN, MU, br. 5/07).

11 Okvirna konvencija Ujedinjenih naroda o klimatskim promjenama iz 1992. godine (engl. The United Nations Framework Convention on Climate Change, dalje: UNFCCC) donesena je u Rio de Janeiru 1992. god., a stupila je na snagu 21. ožujka 1994. god. UNFCCC je ratificiran od strane 191 države i EU-a (vidi Odluku Vijeća 94/69/EZ od 15. prosinca 1993. godine o sklapanju Okvirne konvencije Ujedinjenih naroda o klimatskim promjenama, OJ L 33, 7. veljače 1994. godine, str. 11-12), uključujući i RH (vidi Zakon o potvrđivanju Okvirne konvencije Ujedinjenih naroda o promjeni klime, NN, MU, br. 2/96). 125.

12 DOMINIS, Ž.: „Posljedice stupanja na snagu Protokola iz Kyota“, Naše more, br. 3-4, 2006., str.

13 Protokol iz Kyota propisuje cilj 8-postotnog smanjenja emisija stakleničkih plinova za EU, a politika EU-a u području klimatskih promjena predlaže 20-postotno smanjenje u odnosu na razine iz 1990. god. (ZDILAR, M.: Zahtjevi prilagodbe klimatskim promjenama i obveze prema Okvirnoj konvenciji UN-a o promjeni klime, dostupno na www.klima.mzoip.hr/UserDocsImages/Zdilar_Priagodba_k1_ promjenama.pdf, str. 6).

14 Prema odredbi čl. 1. st. 1. pod 5. UNFCCC, stakleničkim plinovima smatramo one plinovite sastavne dijelove atmosfere, kako prirodne tako i antropogenetske, koji apsorbiraju i ponovno emitiraju infracrvenu radijaciju.

15 Vidi ZANNE, M.; TWRDY, E.: Air pollution from maritime transport - the problem of today, op. cit., str. 102 .

16 Engl. International Convention for the Prevention of Pollution from Ships, dalje: Konvencija MARPOL. Donesena je 17. veljače 1973. god. u Londonu, a stupila je na snagu 2. listopada 1983. godine. Do siječnja 2018. godine, 156 država članice su Konvencijke MARPOL (čak 99,42 \% svjetske trgovačke flote) - vidi https://svw.no/aktuelt/aktuelt/20182/oktober/the-global-sulfur-cap-2020--is-the-industryprepared/. Sve države članice EU-a ujedno su i stranke Konvencije MARPOL, uključujući i Republiku Hrvatsku u odnosu na koju je Konvencija MARPOL na snazi od 8. listopada 1991. godine (Odluka o objavljivanju mnogostranih međunarodnih ugovora kojih je Republika Hrvatska stranka na temelju notifikacije o sukcesiji, NN, MU, br. 1/1992). Detaljnije o sprečavanju onečišćenja mora s brodova prema rješenjima Konvencije MARPOL vidjeti kod LUTTENBERGER, A.: Pomorsko upravno pravo, Sveučilište u Rijeci, Pomorski fakultet, Rijeka, 2008., str. 23-25; SERŚIĆ, M.: Međunarodno-pravna zaštita morskog okoliša, Pravni fakultet Sveučilišta u Zagrebu, Zagreb, 2003., str. 83-87; STANKOVIĆ, P.: Pomorske havarije, Śkolska knjiga, Zagreb, 1995., str. 119-121.

17 PAVIĆ, D.: Pomorsko imovinsko pravo, Književni krug, Split, 2006., str. 402. 
Izv. prof. dr. sc. Željka Primorac: Suvremeni pravni izazovi smanjenja emisija stakleničkih plinova iz... Zbornik radova Pravnog fakulteta u Splitu, god. 57, 3/2020, str. 739-757

operativne zahtjeve u pogledu sprečavanja onečišćenja morskog okoliša svim tvarima koje potječu s brodova uključujući i emisije plinova s brodova. Budući da prema odredbi čl. 16. st. 2. pod c) Konvencije MARPOL jasno proizlazi kako izmjene te konvencije može donijeti odgovarajuće tijelo - Odbor za zaštitu morskog okoliša (MEPC) ${ }^{18}$ Međunarodne pomorske organizacije ${ }^{19}$ godine 1997. donio je Protokol o izmjeni Konvencije MARPOL ${ }^{20}$ kojim je usvojen novi Prilog VI. „Pravila o sprečavanju onečišćenja zraka s brodova“". ${ }^{21}$ Prilog VI. Konvencije MARPOL sadrži obvezna pravila koja normiraju emisije s brodova u međunarodnoj plovidbi, ${ }^{22}$ uključujući i emisije stakleničkih plinova iz pomorskog prometa. Predmetna rješenja predstavljaju glavni međunarodni instrument koji se bavi sprečavanjem onečišćenja zraka s brodova, naročito onih tvari štetnih za ozon. ${ }^{23}$ Odredbe Priloga VI. Konvencije MARPOL primjenjuju se na sve brodove (osim ako drugačije nije izričito određeno), a Pravilom 5. Priloga VI. Konvencije MARPOL propisana je obveza podvrgavanja brojnim pregledima svakog broda od 400 BT ili većeg, te svih fiksnih i plutajućih platformi za bušenje kao i drugih platformi. ${ }^{24}$ Prilogom VI. Konvencije MARPOL, poglavljem III. „Zahtjevi za nadzor ispuštanja s brodova“ detaljnije je normirano provođenje nadzora ispuštanja s brodova uključujući tvari koje uništavaju ozon, dušikove okside $\left(\mathrm{NO}_{\mathrm{x}}\right)$, sumporne okside $\left(\mathrm{SO}_{\mathrm{x}}\right)$ i hlapljive organske spojeve. Kako je od donošenja Priloga VI. Konvencije MARPOL do stupanja na snagu istog prošlo 8 godina, već nakon njegova stupanja na snagu krenulo se u izradu revizije Priloga VI. Konvencije MARPOL,${ }^{25}$ stoga je 22. srpnja

18 Engl. Marine Environment Protection Committee.

19 Međunarodna pomorska organizacija (engl. International Maritime Organization, dalje: IMO) specijalizirana je agencija Ujedinjenih naroda nadležna, među ostalim, i za sprečavanje onečišćenja mora s brodova. Više o ulozi IMO-a u normiranju GHG emisija s brodova vidi BODANSKY, D.: „Regulating Greenhouse Gas Emissions from ships: The Role of the International Maritime Organization“, Ocean Law Debates: the 50-year legacy and emerging issues for the years ahead, Brill Nijhoff, 2018., str. 478-501; CHIRCOP, A.; SHAN, D.: „Governance of International Shipping in the Era of Decarbonisation: New Challenges for the IMO?“" u: Maritime Law in Motion, Springer, 2020., str. 97-113.

20 Protokol Konvenciji MARPOL od 26. rujna 1997. godine na snazi je od 19. svibnja 2005. godine. Do danas je Protokolu Konvencije MARPOL iz 1997. godine pristupilo 96 država koje čine 96,72\% svjetske trgovačke flote - vidi Status of IMO Treaties, 12. veljače 2020. godine, str. 174, dostupno na: http://www.imo.org/en/About/Conventions/StatusOfConventions/Documents/Status\%20-\%202020.pdf). Protokol Konvencije MARPOL iz 1997. godine dio je pravnog sustava RH od 2005. godine (više vidi Uredbu o objavi Protokola iz 1997. godine kojim se mijenja i dopunjuje Međunarodna konvencija o sprečavanju onečišćenja s brodova iz 1973, NN, MU, br. 4/2005).

21 Engl. Annex VI. „Regulations for the Prevention of Air Pollution from Ships“, dalje: Prilog VI. Konvencije MARPOL).

22 EYRING, V. et al., Transport impacts on atmosphere and climate: Shipping, op. cit., str. 2.

23 LUTTENBERGER, A., Pomorsko upravno pravo, op. cit., str. 24.

24 Kada se osnovnim ili redovitim pregledom utvrdi da oprema, sustavi, pribor, uređaji i materijal na njima u potpunosti udovoljavaju primjenjivim zahtjevima Priloga VI. Konvencije MARPOL - svakom brodu od 400 BT ili većem (koji obavlja putovanja do luka ili odobalnih terminala koji su pod vlašću drugih stranaka ugovornica) i platformama i postrojenjima za bušenje (koje obavljaju putovanja do voda koje su pod suverenitetom ili vlašću drugih stranaka ugovornica Protokola iz Kyota) izdat će se Međunarodna svjedodžba o sprečavanju onečišcenja zraka (engl. International Air Pollution Prevention Certificate, dalje: svjedodžba IAPP) čija je valjanost 5 godina.

25 Više vidjeti KARIM, S.: Prevention of Pollution of the Marine Environment from Vessels: The Potential and Limits of the International Maritime Organisation, Springer, 2014., str. 51. 
Izv. prof. dr. sc. Željka Primorac: Suvremeni pravni izazovi smanjenja emisija stakleničkih plinova iz... Zbornik radova Pravnog fakulteta u Splitu, god. 57, 3/2020, str. 739-757

2005. godine prihvaćena rezolucija MEPC.132(53) ${ }^{26}$ kojom su izmijenjene odredbe poglavlja II. „Pregled, potvrđivanje i sredstva nadzora“ Priloga VI. Konvencije MARPOL, a izmjene u pogledu zahtjeva za nadzor ispuštanja s brodova (poglavlje III. Prilog VI. Konvencije MARPOL) odnose se samo na proširenje područja nadzora ispuštanja $\mathrm{SO}_{x}$. Daljnja revizija Priloga VI. Konvencije MARPOL uslijedila je 10. listopada 2008. godine kada je prihvaćena rezolucija MEPC.176(58) o izmjeni Priloga VI. Konvencije MARPOL, ${ }^{27}$ kojom su izmijenjene odredbe Pravila 13-14 Priloga VI. Konvencije MARPOL propisujući strože granične vrijednosti u odnosu na smanjenje emisija $\mathrm{NO}_{x}$ i $\mathrm{SO}_{x} \cdot{ }^{28}$

Godine 2011. usvojena je Rezolucija MEPC.203(62) $)^{29}$ kojom su izvršene izmjene i dopune Priloga VI. Konvencije MARPOL uvrštavanjem novih pravila minimalnih standarda energetske učinkovitosti za brodove u Prilog VI. Konvencije MARPOL. ${ }^{30}$ Naime, dodano je poglavlje 4 „Pravila za energetsku učinkovitost brodova“ koje ima za cilj povećati energetsku učinkovitost brodova te smanjiti emisije stakleničkih plinova. ${ }^{31}$ Predmetna pravila propisuju tehničke i operativne mjere: indeks energetske učinkovitosti za nove brodove ${ }^{32}$ i Plan upravljanja energetskom učinkovitosti broda za sve brodove ${ }^{33}$ koje trebaju pridonijeti smanjenju očekivanog porasta emisija stakleničkih plinova posebice što je njihova obvezna primjena predviđena za sve brodove u međunarodnoj plovidbi tj. u cijeloj svjetskoj floti. ${ }^{34}$ Shvaćajući kako primjena EEDI i SEEMP ne može u potpunosti smanjiti emisije stakleničkih plinova iz pomorskog prometa, u cilju jačanja globalnog odgovora na klimatske promjene u svijetu, na 21. zasjedanju UNFCCC-a, dana 12. prosinca 2015. godine u Parizu je

26 Rezolucija MEPC.132(53) o izmjenama Priloga VI. Konvencije MARPOL, dostupno na: https:// www.classnk.or.jp/hp/pdf/activities/statutory/soxpm/resmepc132-53.pdf.

27 Rezolucija MEPC.176(58) o izmjenama Priloga VI. Konvencije MARPOL, dostupno na: http://www.imo.org/en/KnowledgeCentre/IndexofIMOResolutions/Marine-Environment-ProtectionCommittee-\%28MEPC\%29/Documents/MEPC.176\%2858\%29.pdf.

28 Ta su rješenja stupila na snagu 1. srpnja 2010. godine.

29 Rezolucija MEPC.203(62) o izmjenama Priloga VI. Konvencije MARPOL, dostupno na: http://www.imo.org/en/KnowledgeCentre/IndexofIMOResolutions/Marine-Environment-ProtectionCommittee-(MEPC)/Documents/MEPC.203(62).pdf.

30 Više vidi VIKTORELIUS, M.; LUNDH, M.: „Energy efficiency at sea: An activity theoretical perspective on operational energy efficiency in maritime transport“, Energy Research \& Social Science, vol. 52, 2019., str. 1-9.

31 Predmetna rješenja primjenjuju se od 1. siječnja 2013. godine za sve brodove od 400 BT i više koji obavljaju međunarodnu plovidbu (neovisno o državi zastave broda i brodovlasnikovoj državnoj pripadnosti).

32 Engl. Energy Efficiency Design Indeks, dalje: EEDI. Prema tim mjerama od novih brodova očekuje se ispunjavanje minimalnih, obveznih mjera energetske učinkovitosti. Do danas je više od 2700 novih brodova certificirano prema zahtjevima EEDI-a (tako prema PSARAFTIS, H. N.: Sustainable Shipping: A Cross-Disciplinary View, Springer, 2019., str. 454). Detaljnije o pravnom značaju EEDI-ja za energetsku učinkovitost globalnog pomorskog prometa vidi COMER, B.; CHEN, C.; RUTHERFORD, D.: Regulating short-term measures to IMO's minimum 2050 emissions reduction target, Working Paper 2018-13, The International Council on Clean Transportation, str. 1, dostupno na: https://theicct.org/sites/default/files/ publications/IMO_Short_term_potential_20181011.pdf.

33 Engl. Ship Energy Efficiency Mangement Plan, dalje: SEEMP.

34 Brodu koji ispunjava zahtjeve EEDI-a i SEEMP-a izdaje se Međunarodna svjedodžba energetske učinkovitosti (International Energy Efficiency Certificate - Svjedodžba IEE). 
Izv. prof. dr. sc. Željka Primorac: Suvremeni pravni izazovi smanjenja emisija stakleničkih plinova iz... Zbornik radova Pravnog fakulteta u Splitu, god. 57, 3/2020, str. 739-757

donesen Pariški sporazum o klimatskim promjenama ${ }^{35}$ kojim se zamjenjuje pristup zauzet Protokolom iz Kyota. ${ }^{36}$ Riječ je o međunarodnom ugovoru o klimatskim promjenama koji predstavlja novu dinamičnost u borbi protiv klimatskih promjena ${ }^{37}$ uključujući ostvarivanje dugoročnog cilja zadržavanja povišene globalne temperature na razini koja je znatno niža od $2^{\circ} \mathrm{C}$ iznad predindustrijske razine te ulaganja napora da se to povišenje zadrži ispod $1,5^{\circ} \mathrm{C} .{ }^{38}$

\subsection{Globalni sustav prikupljanja podataka o potrošnji loživih ulja na brodovima (IMO DCS)}

Na svojoj 70. sjednici MEPC je 28. listopada 2016. godine donio Rezoluciju MEPC.278(70) ${ }^{39}$ kojom je izmijenjen Prilog VI. Konvencije MARPOL ${ }^{40}$ tj. uvedena su nova pravila kojima se uspostavlja pravni okvir globalnog sustava prikupljanja, izvješćivanja i verifikacije podataka o potrošnji loživih ulja na brodovima. ${ }^{41}$ Radi se o sljedećim novim rješenjima koja propisuju: a) obvezu brodara prikupljati i izraditi godišnje izvješće o potrošnji goriva ${ }^{42}$ te izvještavati o potrošnji goriva prema SEEMP-u za brodove od 5000 BT $^{43}$ i više u međunarodnoj plovidbi (Pravilo 22A); ${ }^{44}$

35 Pariški sporazum o klimatskim promjenama (engl. The Paris Agreement) potpisalo je 195 država, stupio je na snagu 4. studenog 2016. godine, a primjenjuje se od 2020. godine.

36 Protokol iz Kyota uz UNFCCC odobren je od strane EU-a 25. travnja 2002. godine - vidi Odluku Vijeća 2002/358/EZ od 25. travnja 2002. godine o odobravanju, u ime Europske zajednice, Protokola iz Kyota uz Okvirnu konvenciju Ujedinjenih naroda o promjeni klime i zajedničkom ispunjavanju obveza koje iz njega proizlaze, OJ L 130, 15. svibnja 2002. godine, str. 245-247.

37 Više vidi GHEZLOUN, A.; SAIDANE, A.; MERABET, H.: „New commitments in support of the Paris Agreement", Energy Procedia, vol. 119, 2017., str. 10-19. Detaljnije o slabostima Pariškog sporazuma o klimatskim promjenama u pogledu izostanka konkretnog i međunarodnopravno obvezivog mehanizma provedbe vidi SALAJ, Z.: „Međunarodno pravo i izazovi održivog razvoja: klimatske promjene, države koje tonu i migracije“, Zagrebačka pravna revija, vol. 6, br. 2, 2017., str. 225.

38 EU je ratificirao Pariški sporazum o klimatskim promjenama 5. listopada 2016. godine (vidi Odluku Vijeća (EU) 2016/1841 od 5. listopada 2016. o sklapanju, u ime Europske unije, Pariškog sporazuma donesenoga u sklopu Okvirne konvencije Ujedinjenih naroda o klimatskim promjenama, OJ L 282, 19.10.2016, str. 1-3) te je ona prvo veliko svjetsko gospodarstvo koje je svoj doprinos na temelju Pariškog sporazuma o klimatskim promjenama uvelo u konkretno zakonodavstvo (tako prema: Komunikacija Komisije Europskom parlamentu, Vijeću, Europskom gospodarskom i socijalnom odboru i Odboru regija „,Ujedinjeni u ostvarivanju energetske unije i klimatske politike: postavljanje temelja za uspješan prelazak na čistu energiju“", COM/2019/285 final, 18. lipnja 2019. godine, str. 5, dostupno na: https://op.europa. eu/en/publication-detail/-/publication/62ee9843-92aa-11e9-9369-01aa75ed71a1/language-hr). Republika Hrvatska potpisala je Pariški sporazum o klimatskim promjenama dana 22. travnja 2016. godine (vidi Odluku o proglašenju Zakona o potvrđivanju Pariškog sporazuma, NN, MU, br. 3/2017).

39 Više vidi: Rezolucija MEPC.278(70) o izmjenama Priloga VI. Konvencije MARPOL, dostupno na: http://www.imo.org/en/OurWork/Environment/PollutionPrevention/AirPollution/Documents/278(70). pdf.

40 Izmijenjeni Prilog VI. Konvencije MARPOL stupio je na snagu 1. ožujka 2018. godine.

41 Više vidi NARULA, K.: The Maritime Dimension of Sustainable Energy Security, Springer, 2019., str. 204.

42 Prikupljanje podataka o gorivu započelo je 1. siječnja 2019. godine, a izješćivanje započinje krajem ožujka 2020. godine.

43 Brodovi od 5000 BT i više uzrokuju ukupno 85 \% emisija stakleničkih plinova (IMO, Greenhouse Gas Emissions, op. cit., str. 1).

44 Engl. "Collection and reporting of ship fuel oil consumption data". 
b) opis metodologije prikupljanja predmetnih podataka prema SEEMP-u, od 31 . prosinca 2018. godine (novi st. 2. Pravila 22)..$^{45}$

Uvođenje novog Pravila 22A predstavlja prihvaćanje obveznog, globalnog sustava prikupljanja podataka o potrošnji loživih ulja na brodovima ${ }^{46}$ koji je dio Priloga VI. Konvencije MARPOL, a čije mjere imaju za cilj smanjiti emisije stakleničkih plinova iz pomorskog prometa. ${ }^{47}$ Sustav IMO DCS na snazi je od 1. ožujka 2018. godine, ${ }^{48}$ a u travnju 2018. godine u IMO-u (na 72. sjednici MEPC.304(72) $)^{49}$ postignut je dogovor o Strategiji smanjenja emisija stakleničkih plinova iz međunarodnog pomorskog prometa $^{50}$ u cilju smanjenja navedenih emisija za 50 posto do 2050 . god. odnosno s krajnjim ciljem izvršenja konačne dekarbonizacije pomorskog sektora što prije u 21 . st. ${ }^{51}$

\section{EMISIJE STAKLENIČKIH PLINOVA IZ POMORSKOG PROMETA - EUROPSKA KLIMATSKO-POMORSKA POLITIKA}

U EU više od 30 posto konačne potrošnje energije otpada na promet, a 94 posto prometa ovisi o naftnim proizvodima. ${ }^{52} \mathrm{Na}$ temelju toga ne čudi činjenica kako je u 2017. godini, 27 posto emisija stakleničkih plinova rezultat odvijanja prometa. ${ }^{53}$ Jedan od prioriteta ostvarivanja održivog rasta Europe do 2020. godine predstavljalo je ispunjenje klimatsko-energetskih ciljeva ${ }^{54}, 20 / 20 / 20 “$ uključujući i

45 Prema Pravilu 22 Priloga VI. Konvencije MARPOL, svaki brod od 5000 BT ili više u međunarodnoj plovidbi dužan je od 1. siječnja 2013. godine imati SEEMP.

46 Engl. Data collection system for fuel oil consumption of ships, dalje: IMO DCS.

47 Više vidi HILDRETH, R.; TORBITT, A.: „International Treaties and U.S. Laws as Tools to Regulate the Greenhouse Gas Emissions from Ships and Ports", The International Journal of Marine and Coastal Law, vol. 25, br. 3, 2010., str. 347-376.

48 Vidi Status of IMO Treaties, op. cit., str. 180-181.

49 Rezolucija MEPC.304(72) o strategiji smanjenja emisija stakleničkih plinova s brodova, dostupno na: http://www.imo.org/en/KnowledgeCentre/IndexofIMOResolutions/Marine-Environment-ProtectionCommittee-\%28MEPC\%29/Documents/MEPC.304\%2872\%29.pdf.

${ }^{50}$ Initial IMO Strategy on Reduction of GHG Emissions from Ships (dalje: Strategija). Tekst Strategije dostupan na: https://unfccc.int/sites/default/files/resource/250_IMO\%20submission_Talanoa\%20 Dialogue_April\%202018.pdf

51 Više vidi JOUNG, T.-H.; KANG, S.-G.; LEE, J.-K.; AHN, J.: „The IMO initial strategy for reducing Greenhouse Gas(GHG) emissions, and its follow-up actions towards 2050“, Journal of International Maritime Safety, Environmental Affairs, and Shipping, vol. 4, br. 1, 2020., str. 2.

52 Rezolucija Europskog parlamenta od 15. prosinca 2015. godine o inicijativi „Ususret europskoj energetskoj uniji“, 2017/C 399/03, 24. studenoga 2017. godine, OJ C 399, str. 21-47 (dalje: Rezolucija „Ususret europskoj energetskoj uniji - 2015“).

53 Greenhouse gas emissions from transport in Europe, 2019., str. 1, dostupno na: https://www. eea.europa.eu/data-and-maps/indicators/transport-emissions-of-greenhouse-gases/transport-emissionsof-greenhouse-gases-12.

54 Europski energetski i klimatski ciljevi inkorporirani su u Pariški sporazum o klimatskim promjenama (više vidi LIOBIKIENE, G.; BUTKUS, M.: „The European Union possibilities to achieve targets of Europe 2020 and Paris agreement climate policy“, Renewable Energy, vol. 106, 2017., str. 293-309; XU, H.; LI, Y.; HUANG, H.: „Spatial Research on the Effect of Financial Structure on $\mathrm{CO}_{2}$ Emission“, Energy Proceedia, vo.118, 2017, str. 179-183. 
Izv. prof. dr. sc. Željka Primorac: Suvremeni pravni izazovi smanjenja emisija stakleničkih plinova iz... Zbornik radova Pravnog fakulteta u Splitu, god. 57, 3/2020, str. 739-757

povećanje do 30 posto smanjenja emisija tj. smanjenje emisija stakleničkih plinova za barem 20 posto u odnosu na razine iz 1990. godine, odnosno za 30 posto ukoliko to dozvoljavaju uvjeti. ${ }^{55}$

U odnosu na emisije stakleničkih plinova iz pomorskog prometa, još je Bijelom knjigom Europske komisije „Plan za jedinstveni europski prometni prostor“ iz 2011. godine ${ }^{56}$ naglašeno kako navedene emisije treba smanjiti za najmanje 60 posto do 2050. godine (u usporedbi s razinama iz 1990. godine) odnosno za 20 posto do 2030. godine (u odnosu na razine iz 2008. godine). ${ }^{57}$ Emisije stakleničkih plinova iz pomorskog prometa nisu obuhvaćene sustavom trgovanja emisijskim jedinicama koji se odnosi na emisije nastale u određenim gospodarskim sektorima (energetskom i industrijskom sektoru te sektoru zračnog prometa) ${ }^{58}$ koje su kao takve na europskoj razini normirane Direktivom 2003/87/EZ. ${ }^{59}$ Emisije stakleničkih plinova iz pomorskog prometa nisu obuhvaćene niti Odlukom br. 406/2009/EZ ${ }^{60}$ kojom su utvrđeni minimalni doprinosi država članica EU-a u ispunjavanju obveze smanjivanja emisija stakleničkih plinova za razdoblje od 2013. do 2020. godine u odnosu na emisije stakleničkih plinova u sektorima izvan sustava trgovanja emisijskim jedinicama stakleničkih plinova unutar Zajednice tj. u odnosu na emisije nastale kao rezultat dijela industrijskih procesa, poljoprivrede, šumarstva, gospodarenja otpadom i dr.

Rezolucijom Europskog parlamenta „Ususret europskoj energetskoj uniji“ iz 2015. godine jasno je naglašeno kako je međunarodni pomorski promet isključen iz obveza smanjenja emisija stakleničkih plinova iako bilježi veliku stopu porasta prometa te je predloženo Europskoj komisiji donošenje zakonodavnog prijedloga o ciljevima smanjenja stakleničkih plinova za međunarodni pomorski promet, osim ako se do kraja 2016. godine ne dogovore mjere u okviru IMO-a ${ }^{61}$

55 Europska komisija, Europa 2020: Strategija za pametan, održiv i uključiv rast, COM(2010) 2020 final, 3. ožujka 2010. godine, materijal dostupan na: https://strukturnifondovi.hr/wp-content/ uploads/2017/03/Strategija-EUROPA-2020.-hr.pdf, str. 6, 13.

56 Bijela knjiga Europske komisije Plan za jedinstveni europski prometni prostor, COM(2011) 144 final, 28. ožujka 2011. godine, dostupno na: https://eur-lex.europa.eu/legal-content/EN/TXT/PDF/?uri=C ELEX:52011DC0144\&from=HR

57 Bijela knjiga Europske komisije Plan za jedinstveni europski prometni prostor, op. cit., str. 3.

58 Detaljnije vidi GU, J.; WALLACE, S. W.; WANG, X.: „Can an Emission Trading Scheme really reduce $\mathrm{CO}_{2}$ emissions in the short term? Evidence from a maritime fleet composition and deployment model“", Transportation Research Part D: Transport and Environment, vol. 74, 2019., str. 318-338; KUJANPÄ̈̈, L.; TEIR, S.: „Implications of the New EU Maritime Emission Monitoring Regulation on Ship Transportation of $\mathrm{CO}_{2}$ “"Energy Procedia, vol. 114, 2017., str. 7418.

59 Direktiva 2003/87/EZ Europskog parlamenta i Vijeća od 13. listopada 2003. o uspostavi sustava trgovanja emisijskim jedinicama stakleničkih plinova unutar Zajednice (OJ L 275, 25. listopada 2003. godine, str. 32-46, dalje: Direktiva 2003/87/EZ) uspostavlja sustav za trgovanje emisijama stakleničkih plinova и EU-u s ciljem promicanja smanjenja emisija stakleničkih plinova na način koji je učinkovit u troškovnom i gospodarskom smislu (čl. 1. Direktive 2003/87/EZ).

60 Odluka Europskog parlamenta i Vijeća br. 406/2009/EZ od 23. travnja 2009. godine o naporima koje poduzimaju države članice radi smanjenja emisija stakleničkih plinova s ciljem ostvarenja ciljeva Zajednice vezanih za smanjenje emisija stakleničkih plinova do 2020. godine (OJ L 140, 5. lipnja 2009. godine, str. 136-148, dalje: Odluka br. 406/2009/EZ).

61 Vidi Rezolucija „Ususret europskoj energetskoj uniji - 2015“, op. cit., str. 44. 


\subsection{Uredba (EU) 2015/757 o praćenju emisija ugljikova dioksida iz pomorskog prometa, izvješćivanju o njima i njihovoj verifikaciji}

Prvi korak u izgradnji globalnog sustava praćenja, izvješćivanja i verifikacije emisija $\mathrm{CO}_{2}$ iz pomorskog prometa čine pravne norme donesene Uredbom (EU) br. $2015 / 757^{62}$ kojom je na europskoj razini stvoren pravni okvir praćenje emisija $\mathrm{CO}_{2}{ }^{63}$ s brodova ${ }^{64}$ (čl. 1. Uredbe (EU) 2015/757) ${ }^{65}$ neovisno o zastavi koju brodovi viju. ${ }^{66}$ Društva tj. brodovlasnik ili bilo koja druga organizacija koja je od brodovlasnika preuzela odgovornost za rad broda ${ }^{67}$ bila su dužna do 31 . kolovoza 2017. godine podnijeti akreditiranim verifikatorima ${ }^{68}$ Plan praćenja, koji je sadržavao tehničke specifikacije i odabrane metode praćenja emisija $\mathrm{CO}_{2}$ iz pomorskog prometa, za svaki od svojih brodova. Od 1. siječnja 2018. godine započelo je prvo razdoblje izvješćivanja, ${ }^{69}$ a društva su dužna pratiti emisiju $\mathrm{CO}_{2}$ za svaki brod po putovanju te pratiti, prijavljivati, izvještavati i verificirati emisije $\mathrm{CO}_{2}$ na godišnjoj razini (na temelju potrošnje goriva brodova). Od 30. travnja 2019. godine društva su dužna za svaki brod pod svojom odgovornošću podnijeti Izvješće o emisijama Komisiji i nadležnim tijelima predmetnih država zastave.

\subsection{Prijedlog izmjena Uredbe (EU) $2015 / 757$ iz 2019. godine}

Iako se sve europske i međunarodne inicijative zalažu za međunarodnu unifikaciju i jednoobraznost jer najučinkovitiji pristup smanjenju emisija stakleničkih plinova iz pomorskog prometa (na globalnoj razini) predstavlja uspostava međunarodnopravnog sustava koji bi bio obvezujući za sve države svijeta, rješenja Uredbe (EU) 757/2015 predstavljaju europski standard koji nije globalno prihvaćen

62 Uredba (EU) 2015/757 o praćenju emisija ugljikova dioksida iz pomorskog prometa, izvješćivanju o njima i njihovoj verifikaciji (OJ L 123, 19. svibnja 2015. godine, str. 55-76, dalje: Uredba (EU) 2015/757), donesena 29. travnja 2015. godine, na snazi od 1. srpnja 2015. godine.

63 Rješenjima Uredbe (EU) 2015/757 pokriveno je praćenje, prijavljivanje, izvještavanje i verificiranje samo emisija $\mathrm{CO}_{2}$ s brodova, ne i ostalih stakleničkih plinova (vidi DOBSON, N. L.; RYNGAERT, C.: „Provocative climate protection: EU „extraterritorial“ regulation of maritime emissions“, International and Comparative Law Quarterly, vol. 66, br. 2, 2017, str. 309).

${ }^{64}$ Prema odredbi čl. 2. st. 1. Uredbe (EU) 2015/757, njezina se rješenja primjenjuju na brodove teže od 5000 BT u pogledu emisija $\mathrm{CO}_{2}$ ispuštenih tijekom putovanja iz njihove zadnje luke pristajanja do luke pristajanja pod nadležnošću države članice te od luke pristajanja pod nadležnošću države članice do njihove sljedeće luke pristajanja, kao i unutar luka pristajanja pod nadležnošću države članice.

65 Detaljnije vidi JESSEN, H.: „Commentary on Regulation (EU) 2015/757 on the Monitoring, Reporting and Verification of Carbon Dioxide Emissions from Maritime Transport", EU Maritime Transport Law, C. H. Beck Nomos Hart, 2016., str. 1078-1116; DOBSON, N. L.; RYNGAERT, C.; op. cit., str. 295-333.

66 BASSE, M. E.: ,The European Union's Role in the Development of Global Environmental Law“, Globalization: Strategies and Effects, Springer, 2017., str. 422.

67 Čl. 3. st. 1. pod d) Uredbe (EU) 2015/757.

68 Verifikatori su pravni subjekt koji provode aktivnosti verifikacije, a kojem akreditaciju dodjeljuje nacionalno akreditacijsko tijelo (vidi čl. 3. st. 1 pod f) Uredbe (EU) 2015/757).

69 Više vidi HUARTE MELGAR, B.: „EU energy law in the maritime sector“, Research Handbook on EU Energy Law and Policy, Edward Elgar Publishing, 2017., str. 338. 
Izv. prof. dr. sc. Željka Primorac: Suvremeni pravni izazovi smanjenja emisija stakleničkih plinova iz... Zbornik radova Pravnog fakulteta u Splitu, god. 57, 3/2020, str. 739-757

odnosno europski nadstandard u odnosu na međunarodna pravna rješenja koja su bila na snazi početkom primjene Uredbe (EU) 2015/757.

Uzimajući u obzir kako je u listopadu 2016. godine IMO uspostavio IMO DCS, Odlukom Vijeća (EU) 2016/2077 od 17. listopada 2016. godine ${ }^{70}$ dana je suglasnost u ime EU-a za donošenje izmjena poglavlja 4. Priloga VI. Konvenciji MARPOL koje je trebalo zauzeti na 70. sjednici MEPC-a. Budući da je odredbom čl. 22. st. 3. Uredbe (EU) 2015/757 propisano kako je, u slučaju postizanja međunarodnog sporazuma o globalnom sustavu za praćenje emisija stakleničkih plinova, izvješćivanje o njima i njihovu verifikaciju ili o općim mjerama za smanjenje emisija stakleničkih plinova iz pomorskog prometa, Komisija dužna preispitati Uredbu (EU) 2015/757 i predložiti njezine izmjene - donošenje izmjena poglavlja 4. Priloga VI. Konvencije MARPOL predstavlja započinjanje procesa preispitivanja Uredbe (EU) 2015/757 kako bi se osigurala usklađenost postojećih europskih rješenja s međunarodnopravnim rješenjima tj. s globalnim sustavom IMO DCS.

Rješenja IMO DCS u određenoj mjeri ${ }^{71}$ odgovaraju rješenjima Uredbe (EU) 2015/575, no brodarska društva na koje se odnosi Uredba (EU) 2015/757 (u pogledu brodova težih od 5000 BT koji dolaze u luke Unije, polaze iz tih luka ili se u njima nalaze) imala su obvezu prikupljanja podataka o potrošnji goriva godinu dana prije što uključuje i dodatno administrativno opterećenje, ali i obvezu prikupljanja podataka o prevezenom teretu koje nema u međunarodnim propisima. Nadalje, od 1. siječnja 2019. godine započelo je prikupljanje podataka o gorivu prema IMO DCS (za sve brodove od 5000 BT i više u međunarodnoj pomorskoj plovidbi) pa brodarska društva čiji brodovi iznad 5000 BT dolaze u luke EU-a, polaze iz tih luka ili se u njima nalaze moraju ispunjavati dvostruke zahtjeve glede praćenja i izvješćivanja o emisijama $\mathrm{CO}_{2}$ iz pomorskog prometa: prema rješenjima Uredbe (EU) 2015/757 i prema IMO DCS.

Namjera Europske komisije je Prijedlogom Uredbe Europskog parlamenta i Vijeća o izmjeni Uredbe (EU) 2015/757 72 smanjiti administrativno opterećenje za brodove koji obavljaju djelatnost pomorskog prijevoza i obuhvaćeni su Uredbom

70 Odluka Vijeća (EU) 2016/2077 od 17. listopada 2016. godine o stajalištu koje treba zauzeti u ime Europske unije u okviru Međunarodne pomorske organizacije (IMO) tijekom 70. sjednice Odbora za zaštitu morskog okoliša i 97. sjednice Odbora za pomorsku sigurnost o donošenju izmjena Priloga VI. Konvencije MARPOL, OJ L 320, 26. studenoga 2016. godine, str. 36-39.

71 Više o različitosti rješenja Uredbe (EU) 2015/757 i globalnog sustava IMO DCS vidi European Commission, Commission Staff Working Document - Impact Assessment, Proposal for a Regulation of the European Parliament and of the Council amending Regulation (EU) 2015/757 in order to take appropriate account of the global data collection system for ship fuel oil consumption data, SWD (2019.) 10 final, 4. veljače 2019. godine, dostupno na: https://eur-lex.europa.eu/legal-content/EN/ TXT/?uri=SWD:2019:010:FIN, str. 12-14.

72 Europska komisija, Prijedlog Uredbe Europskog parlamenta i Vijeća o izmjeni Uredbe (EU) 2015/757 kako bi se na odgovarajući način uzeo u obzir globalni sustav prikupljanja podataka o potrošnji loživih ulja na brodovima, COM (2019) 38 final, Bruxelles, 4. veljače 2019. godine, dostupno na: https:// eur-lex.europa.eu/legal-content/HR/TXT/?uri=COM:2019:0038:FIN (dalje: Prijedlog izmjene Uredbe (EU) 2015/757 iz 2019. godine). Kako bi se osiguralo dosljedno provođenje praćenja, izvješćivanja i verifikacije emisija $\mathrm{CO}_{2}$ iz pomorskog prometa, čl. 2. Prijedloga izmjene Uredbe (EU) 2015/757 iz 2019. godine propisuje kako če se izmijenjena Uredba (EU) $2015 / 757$ početi primjenjivati od 1 . siječnja nakon godine njezina stupanja na snagu. 
Izv. prof. dr. sc. Željka Primorac: Suvremeni pravni izazovi smanjenja emisija stakleničkih plinova iz... Zbornik radova Pravnog fakulteta u Splitu, god. 57, 3/2020, str. 739-757

(EU) 2015/757 i globalnim sustavom IMO DCS, a pri tome ne mijenjati bitne ciljeve djelovanja EU-a u tom području. ${ }^{73}$ Prijedlogom izmjene Uredbe (EU) 2015/757 iz 2019. godine Europska komisija se odlučila uskladiti rješenja Uredbe (EU) 2015/757 i globalnog sustava IMO DCS pojednostavljivanjem definicija, parametara praćenja, planova praćenja i obrazaca za praćenje. ${ }^{74}$ Predložene izmjene sadržane su u: a) čl. 1. st. 1. Prijedloga izmjene Uredbe (EU) 2015/757 iz 2019. godine u odnosu na novo pravno poimanje ${ }^{75}$ društva $^{76}$ i razdoblja izvješćivanja ${ }^{77}$ te uvođenje novog pojma „,nosivost u tonama“; ${ }^{78}$ b) čl. 1. st. 2. Prijedloga izmjene Uredbe (EU) 2015/757 iz 2019. godine u odnosu na prijedlog novih rješenja racionalizacije elemenata sadržaja plana praćenja; ${ }^{79}$ c) čl. 1. st. 3. Prijedloga izmjene Uredbe (EU) 2015/757 iz 2019. godine u odnosu na prijedlog novih rješenja kojima društva u odnosu na praćenje po osnovi pojedinačnog putovanja prate pokazatelje glede sati plovidbe ${ }^{80}$ i prevezenog tereta (neobvezno); ${ }^{81}$ d) čl. 1. st. 4. Prijedloga izmjene Uredbe (EU) 2015/757 iz

73 Prijedlog izmjene Uredbe (EU) 2015/757 iz 2019. godine, str. 4.

74 Prijedlog izmjene Uredbe (EU) 2015/757 iz 2019. godine, pod 10.

75 Cilj izmjena pravnog poimanja društva i razdoblja izvješćivanja ima za cilj osigurati odgovornost istih pravnih subjekata za praćenje tijekom slično izračunanih razdoblja ako su djelatnosti brodova obuhvaćene obama sustavima (Prijedlog izmjene Uredbe (EU) 2015/757 iz 2019. godine, pod 11).

76 Društvo znači brodovlasnik ili bilo koja druga organizacija ili osoba, na primjer upravitelj ili zakupnik broda bez posade, koja je od brodovlasnika preuzela odgovornost za rad broda i pristala je preuzeti sve dužnosti i odgovornosti uvedene Uredbom (EZ) br. 336/2006 Europskog parlamenta i Vijeća (riječ je o izmjeni čl. 3. st. 1. pod d) Uredbe (EU) 2015/757).

77 Razdoblje izvješćivanja znači razdoblje od 1. siječnja do 31. prosinca, uključujući i ta dva datuma. Za putovanja koja počinju i završavaju u dvije različite kalendarske godine, odgovarajući podaci ulaze u predmetnu kalendarsku godinu (riječ je o izmjeni čl. 3. st. 1. pod m) Uredbe (EU) 2015/757).

78 Nosivost u tonama znači razliku u tonama između istisnine broda u vodi relativne gustoće 1025 $\mathrm{kg} / \mathrm{m}^{3}$ na ljetnom teretnom gazu i mase praznog opremljenog broda. Trebalo bi smatrati da je ljetni teretni gaz maksimalni ljetni teretni gaz koji je certificiran u knjizi stabilnosti koju je odobrila uprava ili organizacija koju je priznala uprava (riječ je o pojmu koji nije definiran Uredbom (EU) 2015/757, a predlaže se njegovo definiranje u čl. 3. st. 1. pod p) Uredbe (EU) 2015/757). Odredbe globalnog sustava IMO DCS koje se odnose na podatke koje treba pratiti i o njima izvješćivati jednom godišnje uključujući i podatke o parametru nosivosti u tonama pa se po uzoru na rješenja IMO DCS predlaže izvještavati i o tom pokazatelju (vidi Prijedlog izmjene Uredbe (EU) 2015/757 iz 2019. godine, pod 12).

79 Nova rješenja propisuju kako sadržaj plana praćenja treba uključivati pojedinosti o brodu (uključujući njegovo ime, njegov identifikacijski broj pri IMO-u, vrstu broda i naziv društva); opis brodskih motora i drugih potrošača loživog ulja te vrste loživog ulja; i emisijske faktore (riječ je o izmjeni čl. 6. st. 3. a-c) Uredbe (EU) 2015/757); brišu se odredbe prema kojima sadržaj plana praćenje obuhvaća opis postupaka, sustava i odgovornosti upotrijebljenih za ažuriranje popisa izvora emisija $\mathrm{CO}_{2}$ tijekom razdoblja izvješćivanja te pojedinačne emisijske faktore za svaku vrstu goriva (riječ je o brisanju odredbi čl. 6. st. 3. pod d) i g) Uredbe (EU) 2015/757); zamjenjuju se odredbe o opisu postupaka za utvrđivanje podataka o aktivnosti po putovanju koje po Prijedlogu izmjene Uredbe (EU) 2015/757 iz 2019. godine uključuje postupke, odgovornost, formule i izvore podataka za utvrđivanje i bilježenje sati plovidbe (riječ je o izmjeni čl. 6. st. 3. pod h) Uredbe (EU) 2015/757; Europska komisija javno obznanjuje svoje informacije o emisijama $\mathrm{CO}_{2}$ uključujući i informacije o ukupnom godišnjem broju sati plovidbe prema čl. 1. st. 6. Prijedloga izmjene Ưredbe (EU) 2015/757 iz 2019. godine) te nove odredbe kojom sadržaj plana praćenja čine i podaci o kvaliteti podataka, uključujući postupke za utvrđivanje praznina u podacima i rješavanje tog problema (riječ je o izmjeni čl. 6. st. 3. pod i) Uredbe (EU) 2015/757).

80 Sati plovidbe (terminologija koji koristi IMO DCS) trebaju zamijeniti vrijeme provedeno na moru koje kao pokazatelj navodi čl. 9. st. 1. pod e) Uredbe (EU) 2015/757.

${ }_{81}$ Prijedlogom izmjene Uredbe (EU) 2015/757 iz 2019. godine jasno je naznačeno kako društvo nije obvezno pratiti pokazatelj prevezenog tereta dakle, riječ je o neobveznoj stavki praćenja (rješenja čl. 9. st. 1. pod f) Uredbe (EU) 2015/757 ne propisuju neobvezatnost!) što odgovara rješenjima IMO DCS. 
Izv. prof. dr. sc. Željka Primorac: Suvremeni pravni izazovi smanjenja emisija stakleničkih plinova iz... Zbornik radova Pravnog fakulteta u Splitu, god. 57, 3/2020, str. 739-757

2019. godine prema kojem društvo prilikom praćenja po godišnjoj osnovi prati pokazatelj ukupnog broja sati plovidbe ${ }^{82}$ e) čl. 1. st. 5. Prijedloga izmjene Uredbe (EU) 2015/757 iz 2019. godine u odnosu na sadržaj izvješća o emisijama kojega, u slučaju promjene društva, prethodno društvo ${ }^{83}$ dostavlja Europskoj komisiji i tijelima predmetne države zastave (na dan što bliži datumu završetka promjene, a najkasnije u roku od tri mjeseca od promjene), a koje sadržava i informacije o nosivosti broda u tonama ${ }^{84}$ i f) čl. 1. st. 7. Prijedloga izmjene Uredbe (EU) 2015/757 iz 2019. godine glede izmjene Priloga II. "Praćenje drugih relevantnih informacija", dio A (Praćenje po putovanju - čl. 9.) Uredbe (EU) 2015/757 prema kojemu se sati plovidbe izračunavaju kao ukupno vrijeme koje je brod proveo ploveći s pomoću vlastitog poriva, a prijeđena udaljenost se izračunava kao udaljenost preko dna. ${ }^{85}$

$\mathrm{Na}$ temelju iznesenoga uviđamo kako je riječ o izmjenama koje predstavljaju tehničku prilagodbu rješenjima IMO DCS, a neriješenima su ostala važna pitanja glede nadležnih tijela za verifikaciju i način provedbe verifikacije, stavke za praćenje i objavu osjetljivih poslovnih podataka.$^{86}$ Prema Mišljenju Europskog gospodarskog i socijalnog odbora iz 2019. godine, predloženo djelomično usklađivanje dovest će do opterećujućih i neučinkovitih dvostrukih zahtjeva za praćenje i izvješćivanje jer obveze u pogledu izvješćivanja ostaju u okviru dvaju različitih sustava: regionalnog - europskog (prema Uredbi (EU) 2015/757) i globalnog (prema IMO DCS) što će, s obzirom na razliku u obrascima izvješćivanja, dovesti do povećanja radnog opterećenja, administrativnog opterećenja i troškova za posadu brodova i pomorski promet. $^{87}$

\section{ZAKLJUČAK}

Ovaj rad bavi se pitanjima uloge pomorskog prometa u ostvarivanju ciljeva održivog razvoja u kontekstu klimatsko-pomorskih politika na europskoj i globalnoj

82 Riječ je o izmjeni čl. 10. st. 1. pod h) Uredbe (EU) 2015/757 koja predviđa praćenje pokazatelja glede ukupnog vremena provedenog na moru.

83 Radi se o mjerama koje propisuju odgovornost prošlog (bivšeg) vlasnika broda za dostavu izvješća o emisijama ukoliko je promjena društva nastupila za vrijeme trajanja razdoblja izvješćivanja.

84 Riječ je o izmjeni čl. 11. st. 2. Uredbe (EU) 2015/757 i novoj odredbi o nosivosti broda u tonama kao podatku koji mora biti naveden u izvješću o emisijama, a koji nije propisan čl. 11. st. 3. Uredbe (EU) 2015/757.

85 Prijedlogom izmjene Uredbe (EU) 2015/757 iz 2019. godine odustalo se od rješenja koja propisuje Prilog II., dio A, t. 1, pod a) i b) Uredbe (EU) 2015/757 prema kojima se: a) vrijeme provedeno na moru računa na temelju podataka o polasku i dolasku u luku te ne uključuje sidrenje i b) prijeđena udaljenost izražava u nautičkim miljama. U oba slučaja, Prijedlogom izmjene Uredbe (EU) 2015/757 iz 2019. godine preuzimaju se rješenja IMO DCS.

86 Mišljenje Europskog gospodarskog i socijalnog odbora o Prijedlogu Uredbe Europskog parlamenta i Vijeća o izmjeni Uredbe (EU) 2015/757 kako bi se na odgovarajući način uzeo u obzir globalni sustav prikupljanja podataka o potrošnji loživih ulja na brodovima (COM(2019) 38 final - 2019/0017(COD)), OJ C 240, 16. srpnja 2019. godine, str. 41-42, dostupno na: https://op.europa.eu/en/publication-detail/-/ publication/01d4b806-a79e-11e9-9d01-01aa75ed71a1/language-hr/format-HTML (dalje: Mišljenje Europskog gospodarskog i socijalnog odbora iz 2019. godine), pod 2.2.

87 Tako prema Mišljenju Europskog gospodarskog i socijalnog odbora iz 2019. godine, pod 2.5. 
razini. Uzimajući u obzir specifičnost pomorske plovidbene djelatnosti, naglašeni globalni karakter pomorskog prometa i posebitost pomorskopravne regulative, autorica ukazuje na značaj odvijanja suvremenog pomorskog prometa za gospodarske sustave svih država svijeta, ali i na negativne konotacije s obzirom na to da brodovi predstavljaju rastući izvor emisija stakleničkim plinovima i na taj način pridonose klimatskim promjenama. U borbi za zaštitu klime predvodi Europska unija u kojoj je od 1. srpnja 2015. godine na snazi Uredba (EU) 2015/757 čija rješenja normiraju praćenje emisija iz pomorskog prometa, izvješćivanja o njima i njihovoj verifikaciji samo u odnosu na emisije $\mathrm{CO}_{2}$ (ne i u odnosu na emisije ostalih stakleničkih plinova!) s brodova težih od 5000 BT koji se nalaze u luci, uplovljavaju/isplovljavaju u/iz luke pod nadležnošću država članica EU-a. Budući da je na međunarodnoj razini na snazi Prilog VI. Konvencije MARPOL koji sadrži obvezna pravila koja normiraju pitanja sprečavanja onečišćenja zraka s brodova (uključujući i emisije stakleničkih plinova iz pomorskog prometa) i zahtjeva za nadzorom tih emisija - autorica naglašava značaj tehničkih i operativnih mjera (EEDI i SEEMP) kojima se propisuju minimalni standardi energetske učinkovitosti brodova, koji imaju za cilj smanjiti potrošnju goriva i time utjecati na ostvarivanje klimatskih promjena uključujući smanjenje emisija stakleničkih plinova iz pomorskog prometa. Iako su predmetna rješenja na snazi od 1. siječnja 2013. godine i uključuju veći broj zahtjeva propisanih Uredbom (EU) 2015/757, izmjenama Priloga VI. Konvencije MARPOL iz 2016. godine uspostavljen je globalni sustav IMO DCS prema kojemu je 1. siječnja 2019. godine započela obveza praćenja (prikupljanja podataka o potrošnji loživih ulja na brodovima od 5000 BT i više u međunarodnoj pomorskoj plovidbi), a obveza izvješćivanja započela je krajem ožujka 2020. godine.

Na temelju iznesenoga možemo uočiti kako su od 2019. godine brodari obvezni provoditi praćenje i izvješćivanje u okviru dvaju sustava: europskog-regionalnog (Uredbe (EU) 2015/757) i globalnog sustava (IMO DCS). Važno je uočiti kako su brodari na koje se odnosi Uredba (EU) 2015/757 bili dužni prikupiti podatke o emisijama $\mathrm{CO}_{2}$ (unutar podataka o potrošnji goriva) čak godinu dana prije početka prikupljanja podataka prema globalnom sustavu IMO DCS. S obzirom na postizanje međunarodnog sporazuma o globalnom sustavu praćenja emisija stakleničkih plinova (u okviru IMO DCS) i upitnu harmonizaciju tih dvaju sustava, Europska komisija je predložila izmjene Uredbe (EU) 2015/757 kako bi se osigurala usklađenost europskih pravnih rješenja s međunarodnima. $U$ radu su analizirane odredbe Prijedloga Europske komisije u pogledu izmjena Uredbe (EU) 2015/757 iz 2019. godine te možemo zaključiti kako je riječ o nepotpunom usklađivanju jer ono obuhvaća jednostavnije definicije, parametre praćenja, planove praćenja i obrasce za praćenje, a neriješena su ostala pitanja glede nadležnih tijela za verifikaciju i način provedbe verifikacije, stavke za praćenje i objavu osjetljivih poslovnih podataka. $S$ obzirom na to da je smanjenje emisija stakleničkih plinova jedan od glavnih izazova u svijetu, a rastući izvor čine emisije stakleničkih plinova iz pomorskog prometa potrebno je osigurati jedinstvenost međunarodnopravnih rješenja koja se ostvaruje unificiranošću na globalnoj razini. 


\section{POPIS LITERATURE:}

\section{KNJIGE:}

1. BASSE, M. E.: „The European Union's Role in the Development of Global Environmental Law“, u: Globalization: Strategies and Effects, Springer, 2017.

2. BODANSKY, D.: Regulating Greenhouse Gas Emissions from ships: The Role of the International Maritime Organization, Ocean Law Debates: the 50-year legacy and emerging issues for the years ahead, Brill Nijhoff, 2018.

3. CHIRCOP, A.; SHAN, D.: „Governance of International Shipping in the Era of Decarbonisation: New Challenges for the IMO?", u: Maritime Law in Motion, Springer, 2020.

4. COLLS, J.; TIWARY, A.: Air pollution, Measurement, Modelling and Mitigation, CRC Press, 2009.

5. HUARTE MELGAR, B.: „EU energy law in the maritime sector“, u: Research Handbook on EU Energy Law and Policy, Edward Elgar Publishing, 2017.

6. KARIM, S.: Prevention of Pollution of the Marine Environment from Vessels: The Potential and Limits of the International Maritime Organisation, Springer, 2014.

7. JESSEN, H.: „Commentary on Regulation (EU) 2015/757 on the Monitoring, Reporting and Verification of Carbon Dioxide Emissions from Maritime Transport", u: EU Maritime Transport Law, C. H. Beck Nomos Hart, 2016.

8. LUTTENBERGER, A.: Pomorsko upravno pravo, Sveučilište u Rijeci, Pomorski fakultet, Rijeka, 2008.

9. NARULA, K.: The Maritime Dimension of Sustainable Energy Security, Springer, 2019.

10. PAVIĆ, D.: Pomorsko imovinsko pravo, Književni krug, Split, 2006.

11. PSARAFTIS, H. N.: Sustainable Shipping: A Cross-Disciplinary View, Springer, 2019.

12. SERŠIĆ, M.: Međunarodno-pravna zaštita morskog okoliša, Pravni fakultet Sveučilišta u Zagrebu, Zagreb, 2003.

13. STANKOVIĆ, P.: Pomorske havarije, Školska knjiga, Zagreb, 1995.

\section{ČLANCI:}

1. BROZOVIĆ, I.; REGENT, A.; GRGUREVIĆ, M.: „Emisije stakleničkih plinova, osobito iz prometa (Prilog analizi emisiji stakleničkih plinova, osobito iz prometa)“, Zbornik Veleučilišta u Rijeci, vol. 2, br. 1, 2014.

2. DOBSON, N. L.; RYNGAERT, C.: „Provocative climate protection: EU „extraterritorial“ regulation of maritime emissions", International and Comparative Law Quarterly, vol. 66, br. 2, 2017.

3. DOMINIS, Ž.: „Posljedice stupanja na snagu Protokola iz Kyota“, Naše more, br. 3-4, 2006. 
4. DULEBENETS, M. A.: „Green Vessel Scheduling in Liner Shipping: Modeling Carbon Emission Costs in Sea and at Ports of Call“", International Journal of Transportation Science and Technology, vol. 7, br. 1, 2018.

5. EYRING, V.; ISAKSEN, I. S. A.; BERNTSEN, T., COLLINS, W. J.; CORBETT, J. J.; ENDRESEN, O.; GRAINGER, R. G.; MOLDANOVA, J.; SCHLAGER, H.; STEVENSON, D. S.: „Transport impacts on atmosphere and climate: Shipping, Atmospheric Environment", 2009.

6. GHEZLOUN, A.; SAIDANE, A.; MERABET, H.: ,New commitments in support of the Paris Agreement“, Energy Procedia, vol. 119, 2017.

7. GRITSENKO, D.: „Regulating GHG Emissions from shipping: Local, global, or polycentric approach?“, Marine Policy, vol. 84, 2017.

8. GU, J.; WALLACE, S. W.; WANG, X.: „Can an Emission Trading Scheme really reduce $\mathrm{CO}_{2}$ emissions in the short term? Evidence from a maritime fleet composition and deployment model“", Transportation Research Part D: Transport and Environment, vol. 74, 2019.

9. HILDRETH, R.; TORBITT, A.: „International Treaties and U.S. Laws as Tools to Regulate the Greenhouse Gas Emissions from Ships and Ports“, The International Journal of Marine and Coastal Law, vol. 25, br. 3, 2010.

10. JOUNG, T.-H.; KANG, S.-G.; LEE, J.-K.; AHN, J.: „,The IMO initial strategy for reducing Greenhouse Gas(GHG) emissions, and its follow-up actions towards 2050“, Journal of International Maritime Safety, Environmental Affairs, and Shipping, vol. 4, br. 1, 2020.

11. KUJANPÄ̈̈, L.; TEIR, S.: „Implications of the New EU Maritime Emission Monitoring Regulation on Ship Transportation of $\mathrm{CO}_{2}$ “, Energy Procedia, vol. 114, 2017.

12. LIOBIKIENE, G.; BUTKUS, M.: „The European Union possibilities to achieve targets of Europe 2020 and Paris agreement climate policy“, Renewable Energy, vol. 106, 2017.

13. MILOŠEVIĆ-PUJO, B.; JURJEVIĆ, N.: „Onečišćenje mora iz zraka emisijom ispušnih plinova“, Naše more, br. 5-6, 2004.

14. POPEK, M.: Response of international shipping to the current environmental challenges, E3S Web of Conferences - SEED 2016, vol. 10, 2016.

15. RAHIM, M. M.; ISLAM, T.; KURUPPU, S.: „Regulating global shipping corporations' accountability for reducing greenhouse gas emissions in the seas“, Marine Policy, vol. 69, 2016., str. 159.

16. SALAJ, Z.: „Međunarodno pravo i izazovi održivog razvoja: klimatske promjene, države koje tonu i migracije“, Zagrebačka pravna revija, vol. 6, br. 2, 2017.

17. SHARMINA, M.; MCGLADE, C.; GILBERT, P., LARKIN, A.: „Global energy scenarios and their implications for future shipped trade“, Marine Policy, vol. 84, 2017. 
18. VIANA, M.; HAMMINGH, P.; COLETTE, A.; QUEROL, X.; DEGRAEUWE, B.; DE VLIEGER, I.; VAN AARDENNE, J.: „Impact of maritime transport emissions on coastal air quality in Europe“, Atmospheric Environment, vol. 90, 2014.

19. VIKTORELIUS, M.; LUNDH, M.: „Energy efficiency at sea: An activity theoretical perspective on operational energy efficiency in maritime transport", Energy Research \& Social Science, vol. 52, 2019.

20. XU, H.; LI, Y.; HUANG, H.: „Spatial Research on the Effect of Financial Structure on $\mathrm{CO}_{2}$ Emission“, Energy Proceedia, vo.118, 2017.

21. WAN, Z.; EL MAKHLOUFI, A.; CHEN, Y., TANG, J.: „Decarbonizing the international shipping industry: Solutions and policy recommendations“, Marine Pollution Bulletin, br. 126, 2018.

22. ZANNE, M.; TWRDY, E.: „Air pollution from maritime transport - the problem of today, the challenges of tommorow“, Pomorstvo, vol. 25, br. 1, 2011.

\section{PRAVNI PROPISI:}

1. Direktiva 2003/87/EZ Europskog parlamenta i Vijeća od 13. listopada 2003. o uspostavi sustava trgovanja emisijskim jedinicama stakleničkih plinova unutar Zajednice, OJ L 275, 25. listopada 2003. godine, str. 32-46.

2. Međunarodna konvencija o sprječavanju onečišćenja mora s brodova iz 1973. godine.

3. Odluka Europskog parlamenta i Vijeća br. 406/2009/EZ od 23. travnja 2009. godine o naporima koje poduzimaju države članice radi smanjenja emisija stakleničkih plinova s ciljem ostvarenja ciljeva Zajednice vezanih za smanjenje emisija stakleničkih plinova do 2020. godine, OJ L 140, 5. lipnja 2009. godine, str. 136-148.

4. Odluka Vijeća 94/69/EZ od 15. prosinca 1993. godine o sklapanju Okvirne konvencije Ujedinjenih naroda o klimatskim promjenama, OJ L 33, 7. veljače 1994. godine, str. 11-12.

5. Odluka Vijeća 2002/358/EZ od 25. travnja 2002. godine o odobravanju, u ime Europske zajednice, Protokola iz Kyota uz Okvirnu konvenciju Ujedinjenih naroda o promjeni klime i zajedničkom ispunjavanju obveza koje iz njega proizlaze, OJ L 130, 15. svibnja 2002. godine, str. 245-247.

6. Odluka Vijeća (EU) 2016/1841 od 5. listopada 2016. o sklapanju, u ime Europske unije, Pariškog sporazuma donesenoga u sklopu Okvirne konvencije Ujedinjenih naroda o klimatskim promjenama, OJ L 282, 19. X. 2016., str. 1-3.

7. Odluka Vijeća (EU) 2016/2077 od 17. listopada 2016. godine o stajalištu koje treba zauzeti u ime Europske unije u okviru Međunarodne pomorske organizacije (IMO) tijekom 70. sjednice Odbora za zaštitu morskog okoliša i 97. sjednice Odbora za pomorsku sigurnost o donošenju izmjena Priloga VI. Konvencije MARPOL, OJ L 320, 26. studenoga 2016. godine, str. 36-39.

8. Odluka o objavljivanju mnogostranih međunarodnih ugovora kojih je Republika Hrvatska stranka na temelju notifikacije o sukcesiji (NN, MU, br. 1/1992).

9. Odluka o proglašenju Zakona o potvrđivanju Pariškog sporazuma (NN, MU, br. 3/2017). 
10. Okvirna konvencija Ujedinjenih naroda o klimatskim promjenama iz 1992. godine.

11. Protokol iz Kyota o klimatskim promjenama iz 1997. godine.

12. Protokol Konvenciji MARPOL iz 1997. godine.

13. Uredba o objavi Protokola iz 1997. godine kojim se mijenja i dopunjuje Međunarodna konvencija o sprečavanju onečišćenja s brodova iz 1973 (NN, MU, br. 4/2005).

14. Uredba (EU) $2015 / 757$ o praćenju emisija ugljikova dioksida iz pomorskog prometa, izvješćivanju o njima i njihovoj verifikaciji, OJ L 123, 19. svibnja 2015. godine, str. 55-76.

15. Zakon o potvrđivanju Kyotskog protokola uz Okvirnu konvenciju Ujedinjenih naroda o promjeni klime (NN, MU, br. 5/07).

16. Zakon o potvrđivanju Okvirne konvencije Ujedinjenih naroda o promjeni klime (NN, MU, br. 2/96).

\section{OSTALA DOKUMENTACIJA:}

1. Bijela knjiga Europske komisije „Plan za jedinstveni europski prometni prostor“, $\operatorname{COM}(2011) 144$ final, 28. ožujka 2011. godine (https://eur-lex.europa.eu/legalcontent/EN/TXT/PDF/?uri=CELEX:52011DC0144\&from=HR).

2. Climate Action, European Commission, Time for international action on $\mathrm{CO} 2$ emissions from shipping (https://ec.europa.eu/clima/.../shipping/.../marine_transport_ en.pdf).

3. COMER, B.; CHEN, C.; RUTHERFORD, D.: Regulating short-term measures to IMO's minimum 2050 emissions reduction target, Working Paper 2018-13, The International Council on Clean Transportation (https://theicct.org/sites/default/files/ publications/IMO_Short_term_potential_20181011.pdf).

4. European Commission, Commission Staff Working Document - Impact Assessment, Proposal for a Regulation of the European Parliament and of the Council amending Regulation (EU) 2015/757 in order to take appropriate account of the global data collection system for ship fuel oil consumption data, $\operatorname{SWD}(2019) 10$ final, 4. veljače 2019. (https://eur-lex.europa.eu/legal-content/EN/TXT/?uri=SWD:2019:010:FIN).

5. Europska komisija, „Europa 2020: Strategija za pametan, održiv i uključiv rast“, COM(2010) 2020 final, 3. ožujka 2010. godine (https://strukturnifondovi.hr/wpcontent/uploads/2017/03/Strategija-EUROPA-2020.-hr.pdf).

6. Europska komisija, Prijedlog Uredbe Europskog parlamenta i Vijeća o izmjeni Uredbe (EU) 2015/757 kako bi se na odgovarajući način uzeo u obzir globalni sustav prikupljanja podataka o potrošnji loživih ulja na brodovima, $\operatorname{COM(2019)~} 38$ final, Bruxelles, 4. veljače 2019. godine (https://eur-lex.europa.eu/legal-content/HR/ TXT/?uri=COM:2019:0038:FIN).

7. EYRING, V.; CORBETT, J. J.; LEE, D. S.; WINEBRAKE, J. J.: Brief summary of the impact of ship emissions on atmospheric composition, climate, and human health, document submitted to the Health and Environment sub-group of the International Maritime Organization, 6. November 2007 (http://citeseerx.ist.psu.edu/viewdoc/dow nload;jsessionid=C39FFDA797B8EBBD65F409C3E56B9FA4?doi=10.1.1.617.736 $1 \&$ rep=rep $1 \&$ type $=$ pdf). 
Izv. prof. dr. sc. Željka Primorac: Suvremeni pravni izazovi smanjenja emisija stakleničkih plinova iz... Zbornik radova Pravnog fakulteta u Splitu, god. 57, 3/2020, str. 739-757

8. Greenhouse gas emissions from transport in Europe, 2019, str. 1 (https://www. eea.europa.eu/data-and-maps/indicators/transport-emissions-of-greenhouse-gases/ transport-emissions-of-greenhouse-gases-12).

9. Green Paper on greenhouse gas emissions trading within the European Union, COM/2000/0087final (https://eur-lex.europa.eu/legal-content/EN/TXT/PDF/?uri=C ELEX:52000DC0087\&from=EN).

10. IMO, Greenhouse Gas Emissions (http://www.imo.org/en/OurWork/Environment/ PollutionPrevention/AirPollution/Pages/GHG-Emissions.aspx).

11. Initial IMO Strategy on Reduction of GHG Emissions from Ships (https://unfecc. int/sites/default/files/resource/250_IMO\%20submission_Talanoa\%20Dialogue_ April\%202018.pdf).

12. Komunikacija Komisije Europskom parlamentu, Vijeću, Europskom gospodarskom i socijalnom odboru i Odboru regija „Ujedinjeni u ostvarivanju energetske unije i klimatske politike: postavljanje temelja za uspješan prlazak na čistu energiju“, COM/2019/285 final, 18. lipnja 2019. godine (https://op.europa.eu/en/publicationdetail/-/publication/62ee9843-92aa-11e9-9369-01aa75ed7lal/language-hr).

13. Mišljenje Europskog gospodarskog i socijalnog odbora o Prijedlogu Uredbe Europskog parlamenta i Vijeća o izmjeni Uredbe (EU) 2015/757 kako bi se na odgovarajući način uzeo u obzir globalni sustav prikupljanja podataka o potrošnji loživih ulja na brodovima (COM(2019) 38 final - 2019/0017(COD)), OJ C 240, 16. srpnja 2019. godine, str. 41-42 (https://op.europa.eu/en/publication-detail/-/publication/01d4b806a79e-11e9-9d01-01aa75ed71a1/language-hr/format-HTML).

14. Rezolucija Europskog parlamenta od 15. prosinca 2015. godine o inicijativi „Ususret europskoj energetskoj uniji““, 2017/C 399/03, 24. studenoga 2017. godine, OJ C 399, str. 21-47.

15. Rezolucija MEPC.132(53) o izmjenama Priloga VI. Konvencije MARPOL (https:// www.classnk.or.jp/hp/pdf/activities/statutory/soxpm/resmepc132-53.pdf).

16. Rezolucija MEPC.176(58) o izmjenama Priloga VI. Konvencije MARPOL (http:// www.imo.org/en/KnowledgeCentre/IndexofIMOResolutions/Marine-EnvironmentProtection-Committee-\%28MEPC\%29/Documents/MEPC.176\%2858\%29.pdf).

17. Rezolucija MEPC.203(62) o izmjenama Priloga VI. Konvencije MARPOL (http:// www.imo.org/en/KnowledgeCentre/IndexofIMOResolutions/Marine-EnvironmentProtection-Committee-(MEPC)/Documents/MEPC.203(62).pdf).

18. Rezolucija MEPC.278(70) o izmjenama Priloga VI. Konvencije MARPOL (http:// www.imo.org/en/OurWork/Environment/PollutionPrevention/AirPollution/ Documents/278(70).pdf).

19. Rezolucija MEPC.304(72) o strategiji smanjenja emisija stakleničkih plinova $\mathrm{s}$ brodova (http://www.imo.org/en/KnowledgeCentre/IndexofIMOResolutions/ Marine-Environment-Protection-Committee-\%28MEPC\%29/Documents/ MEPC.304\%2872\%29.pdf).

20. Status of IMO Treaties, 12. veljače 2020. godine, (http://www.imo.org/en/About/ Conventions/StatusOfConventions/Documents/Status\%20-\%202020.pdf). 
21. Sources of Greenhouse Gas Emissions (https://www.epa.gov/ghgemissions/sourcesgreenhouse-gas-emissions).

22. ZDILAR, M.: Zahtjevi prilagodbe klimatskim promjenama i obveze prema Okvirnoj konvenciji UN-a o promjeni klime (www.klima.mzoip.hr/UserDocsImages/Zdilar_ Priagodba_kl_promjenama.pdf).

\section{WEB-IZVORI:}

1. https://svw.no/aktuelt/aktuelt/20182/oktober/the-global-sulfur-cap-2020--is-theindustry-prepared/

\section{CONTEMPORARY LEGAL CHALLENGES OF REDUCING GREENHOUSE GAS EMISSIONS FROM MARITIME TRANSPORT - INTERNATIONAL AND EUROPEAN PERSPECTIVE}

Presenting an overview of legal acts whose solutions, as a result of active climate and maritime policies at European and global level, guarantee the reduction of greenhouse gas emissions from maritime transport - the author points out the importance of the decision on the introduction of mandatory, global, minimum energy efficiency standards for ships in international shipping. The basic starting point of this research is the analysis of Rule 22A of amended Annex VI. MARPOL Convention which establishes a legal framework for the mandatory global data collection system for fuel oil consumption of ships (IMO DCS), according to which, from 1 January 2019, shipowners are required to collect fuel oil consumption data for ships above 5,000 GT and above in international shipping and to report on fuel oil consumption as of March 2020. Particular attention is paid to the analysis of the regulatory activity of the European legislation of 2019 in relation to the Proposal for a Regulation of the European Parliament and of the Council amending Regulation (EU) 2015/757 and the efforts to achieve full harmonisation of the European and global system of collecting data on emissions and fuel oil consumption on ships, with the aim of reducing greenhouse gas emissions from maritime transport. The focus is on the assessment of the effectiveness of aligning the provisions of Regulation (EU) 2015/757 with the global IMO DCS system under the Proposal for a Regulation of the European Parliament and of the Council amending Regulation (EU) 2015/757 from 2019.

Key words: reducing greenhouse gas emissions, maritime transport, legal challenges 